\title{
Severino in English
}

Translating João Cabral de Melo Neto's long dramatic poem, Morte e Vida Severina (Death and Life of Severino) (1955) was an enormous challenge. The long dramatic poem is so fixed in a well-defined Brazilian cultural situation, the problems of poverty,drought and migration in the Northeast, with many regional terms and specific vocabulary from sugar cane, religion and even crabs. In this essay i intend to look at some of the most difficult problems I had. Let's begin with the term retirante. Migrant was too formal and technical, though I did use in in Cabral's directions, and I chose traveller. Gypsies in Britain often call themselves travellers, and the term new-age travellers, though this perhaps gives the wrong impression of Severino, has entered common usage.

I was lucky with them name Severino, which I of course kept. In Portuguese severo belongs to the same semantic field. In English, as well as severe, we also have to sever, (to cut), which I took advantage of in the following lines:

\author{
And all of us Severinos \\ With the same lives \\ Will die of the same \\ Severe Severino death, \\ The death died of \\ Old age before thirty \\ Of an ambush before twenty \\ And of hunger day by day,
}


I mixed original and translated place names in the following section in order to keep the comic effect. I literally translated Aurora, Espinheiro and Aflitos, Avenida Sul and Avenida Norte, adjusted Tamarineira to Tamarindeira, Cajueira to Casheweira, used Birdtown and Fishtown as comic equivalents of Passarinho and Peixinhos.

\author{
- Here's pineapple from Goiana \\ And sugar cane to suck from all over. \\ - Take these fresh oysters \\ Just gathered in the Bay of the Dawn. \\ - Here are tamarinds from Jaqueira \\ And jackfruit from Tamarindeira. \\ - Mangaba fruit from Casheweira \\ And cashews from Mangabeira. \\ - Fish caught in Birdtown, \\ Beef from Fishtown. \\ - Little crabs caught in the mud \\ At the back of Imperial Street. \\ - Mangoes bought in the wealthy suburbs \\ Of Thornbush and Affliction. \\ - Big crabs given by poor people \\ From North and South Avenues.
}

The most difficult section of the poem was by far the famous graveside lament, set to music by Chico Buarque. This had to rhyme. The amount of time spent on this section was enormous, coming back and back to it. I was quite please with the result. Also note the use of latifundio, which I remember clearly from my Junior School days, when being told 
that there were a lot of minifundios and latifundios in Latin America. I preferred this to ranch (shades of Texas), estate (the Lord of the estate) and farm (too neutral)

He sees the burial of a farm worker and listens to what his friends who take him to the cemetery say.

- The grave you're in

Is measured by hand,

The best bargain you got

In all the land.

- You fit it well,

Not too long or deep,

The part of the latifundio

Which you will keep.

- The grave's not too big,

Nor is it too wide,

It's the land you wanted

To see them divide.

- It's a big grave

For a body so spare,

But you'll be more at ease

Than you ever were.

- You're a skinny corpse

For such a big tomb, But at least down there

You'll have plenty of room.

- The grave is big

For your skin and bone,

But when land is given,

You can hardly moan. 
I also tried to maintain the rhymes, with varying success in the following section:

- You'll live here for ever In the land you have got,

And you'll have your own plot.

- Growing your own ants, Free from the sun and rain, Here you'll always remain.

- Now you'll work for yourself, You won't give up your right arm Working on the boss's farm.

Lord, labourer and tractor, You'll work the soil And get all the spoils.

- Working this land, You'll get no rest,

You'll be seed, fertilizer and harvest.

- You'll work on a land That will clothe you and give you peace In the cloth of the Northeast.

- You'll dress as never before.

And your last shirt

Will be made of dirt.

- It'll be of dirt

And your last shirt.

It'll clothe you and no one will envy you.

- For the first time in your life You'll have a suit

Of soil and a pair of boots. 
- And as you're a man,

You'll get a hat for a male.

If you were a woman, a shawl or veil.

- Your best clothes

Will be of earth and not of cloth.

They won't tear and will never rot.

- In your best clothes

You'll look a man of leisure

With clothes made to measure.

I was pleased with shirt and dirt, so much so that I repeated it in the next stanza. On other occasions I could only get half-rhymes, cloth/rot,peace/ Northeast, and some lines which obtained the rhymes seemed excessively heavy, fertilizer and harvest, and give you peace.

The following lament, which includes maçaroca banguela, tested all my resources in the semantic fields of corn and corn seeds, with terms like mainva (shoot), rebolo de cana (sugar cane sprout), espiga debulhada (threshed husk), espiga no sabugo (chewed up shuck), soca (second harvest), semente maninha (barren seed). The most difficult expression to translate in all the poem was maçaroca banguela. Banguela, "with no front teeth", was reaatively straightforward, but maçaroca was tougher. After questioning some of top experts on Brazilian literature and the Portuguese language, I discovered maçaroca was a very poor kind of soup, into which all the leftovers of corn were put. Thus banguela as all the teeth of corn have already been eaten, and there are just the bare shucks left. My first attempt was toothless stew, but a stew normally contains meat, and can be very tasty. So stew was downgraded to swill; pigs normally eat swill, a mixture a just about anything, any left overs, and so toothless stew became toothless swill.

- This land you know well, It drank the sweat you sold. 
MILTON, John. Severino in English.

- This land you know well,

It sapped up your spirit of youth.

- This land you know well,

It shrank your manliness.

- This land knows you well, Through friends and relations.

- This land knows you well,

You'll live with your wife and children.

- This land knows you well,

It's been waiting since you were born.

- You have no force left,

Let yourself be sown lengthways.

- You have no live seed,

Your body is its own shoot.

- You have no sugar cane sprout.

You are the sprout but not of cane.

- You have no seed in your hand;

You are the grain.

- You have no strength in your leg;

Let yourself be sown in the grave.

- You have no strength in your hand; Let yourself be sown in the furrows.

- In the hammock nothing coming, Only your threshed husk. 
- In the hammock a lot coming,

Only your chewed up shuck.

- In the hammock something scarce,

Toothless swill.

- In the hammock very little,

Your life with no second harvest.

- In your right hand a rosary,

Black dried corn.

- In your right hand only

The rosary, dry seed.

- In the right hand, the rosary

Of ash, barren seed.

- In the right hand the rosary,

Inert and lifeless seed.

- Naked you came in the coffin, Naked also the grain is buried.

- Poverty unclothed you so much, That the wind left your chest.

- You took off so many things in life, That the cool breeze left your chest.

- And now the ground opens to shelter you, The sheet you never had in your life.

- The ground opens and covers you, It gives you blanket and bed.

- The ground opens and wraps you Like a woman to sleep with. 
And finally, João Cabral's very beautiful ending, in which I kept the Portuguese topographical terms. As the English edition is aimed at a public who would have little knowledge of Brazil, I'm planning to include an Introduction and footnotes.

The neighbours, friends and visitors speak.

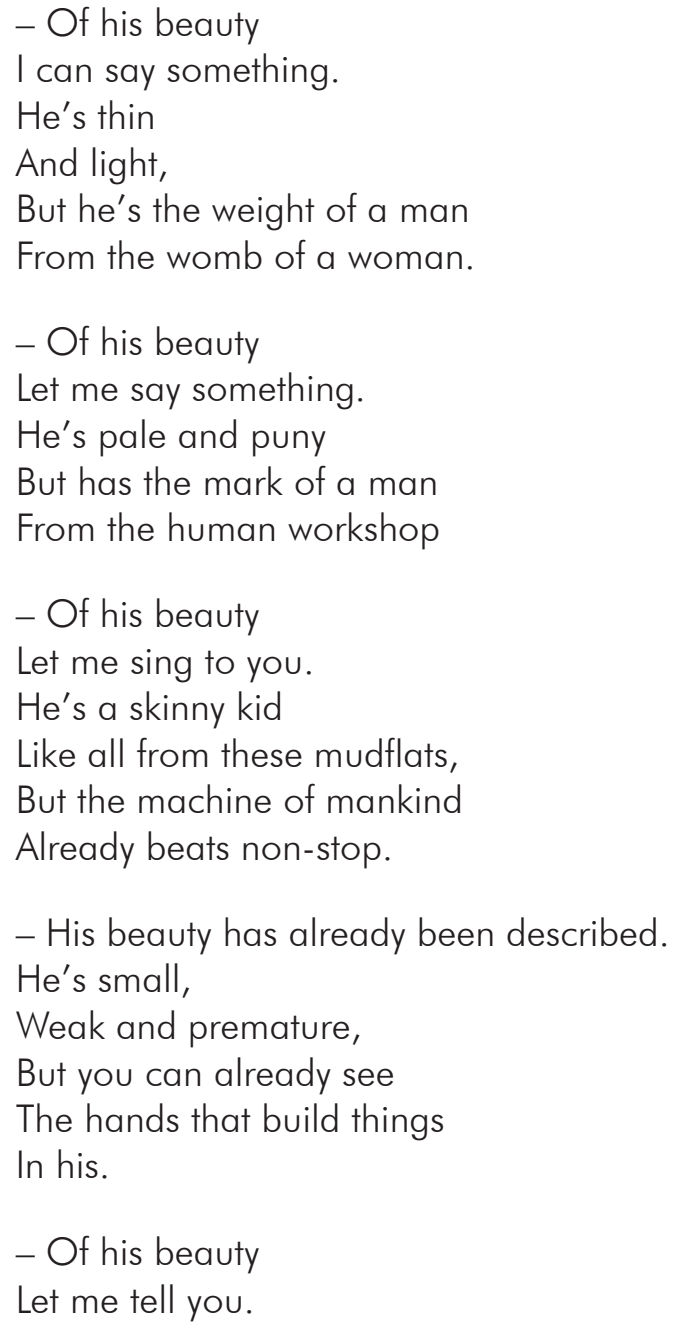


He's as lovely as a coconut tree

That conquers the sea sand.

- Of his beauty

Let me tell you.

He's as lovely as the avelos plant

On the grey Agreste.

- Of his beauty

Let me tell you.

He's as lovely as the prickly pear tree

On the dry Caatinga.

- Of his beauty

Let me tell you.

He's as lovely as a yes

In a room of noes.

- He's as lovely as a second

Harvest of sugar cane.

- Lovely because he's a door

To open more exits.

- Lovely as the last wave

The end of the sea never brings.

As lovely as the waves

- In their infinity.

- Lovely because he has the surprise

And joy of the new.

- Lovely as something new

On an empty shelf. 
MILTON, John. Severino in English.

- Like anything new

Beginning its day.

- Like a new notebook

When we open it.

- Lovely, as the new

Decays the old.

- Lovely, as the new blood

Destroys anemia.

- It infects misery

With life and health.

- An oasis in the desert,

The calm after the storm.

The carpenter speaks to the migrant, who has been outside, not taking part.

- Traveller Severino,

Let me tell you now

I don't know the answer

To your question.

Whether you should

Throw your life

From the bridge.

But I don't know this answer.

If you want me to tell you,

You can't defend

Life with just words,

More so when it's what

You can see, so hard. 
But if I told you

I didn't know the answer,

Life itself told you

(With it's own presence).

And there's no better answer

Than to see life

Unravel its thread,

Which is also called life,

See the factory

Life itself stubbornly makes.

See it sprout and grow, like now,

Explode into a new life,

Even when the explosion,

Like that which too place,

Is so small.

Even when it's so puny,

Even when it's that of

A severe, Severino life. 